\title{
PERBEDAAN KOSAKATA DIALEK MELAYU DI DESA BETUNG DENGAN DESA KESUMA KECAMATAN PANGKALAN KURAS KABUPATEN PELALAWAN
}

\author{
Rieke Nur Safitri ${ }^{1}$, Auzar $^{2}$, Hermandra $^{3}$ \\ Universitas Riau, Pekanbaru, Indonesia ${ }^{1,2,3}$ \\ rike0333@gmail.com ${ }^{1}$, auzarthaher54@gmail.com² , hermandra2312@gmail.com³ $^{3}$
}

\begin{abstract}
This research was motivated by the existence of interest and curiosity about why two villages are very close in the distance, which use the same language but have many differences in the use of vocabulary used in speaking in the daily life of the speech community. Using different vocabulary in the spoken community in Betung and Kesuma villages raises questions about the differences in vocabulary and what factors influence these differences. The research objective was to describe the difference in vocabulary between the two villages. This research is expected to become a reference for similar research and as material to add insight. This research uses vocabulary theory, language variation, and technique. This research is qualitative research using the descriptive analysis method. Data were collected using the method of observation, interviews, proficient listening, and notetaking techniques. The collected data is then reduced, displayed, concluded. Based on the research process that the author has carried out, it was found that the results of the study were the differences in the vocabulary of the Malay dialect used by the speech community between Betung Village and Kesuma Village. The author found 71 differences in vocabulary that will be analyzed based on semantic differences, namely synonyms. The author also found six differences in vocabulary that will be analyzed based on semantic differences, namely homonyms. The author also obtained the study results, namely the factors that influence the vocabulary used by the spoken community in Betung Village and Kesuma Village.

Keywords: Difference, vocabulary, dialect, language variation
\end{abstract}

\section{ABSTRAK}

Penelitian ini dilatarbelakangi oleh adanya ketertarikan dan rasa penasaran mengenai mengapa dua desa yang sangat dekat jaraknya, yang menggunakan bahasa yang sama namun memiliki banyak perbedaan penggunaan kosakata yang dipakai dalam berbicara di kehidupan sehari-hari masyarakat tutur. Adanya kejadian penggunaan kosakata yang berbeda pada masyarakat tutur di Desa Betung dan Desa Kesuma ini menimbulkan pertanyaan, bagaimana perbedaan kosakata tersebut dan faktor apa yang memengaruhi terjadinya perbedaan tersebut. Tujuan penelitian ialah untuk mendeskripsikan perbedaaan kosakata antara kedua desa tersebut. Penelitian ini diharpkan dapat menjadi referensi untuk penelitian serupa dan sebagai bahan menambah wawasan. Penelitian ini menggunakan teori kosakata, variasi bahasa, dan diaek. Penelitian ini penelitian kualitatif yang menggunakan metode analisis deskriptif. Data dikumpulkan dengan metode observasi, wawancara, teknik simak libat cakap, dan teknik catat. Data yang terkumpul kemudian direduksi, di display, disimpulkan. Berdasarkan proses penelitian yang telah dilakukan oleh penulis, ditemukan hasil penelitian yakni perbedaan kosakata dialek Melayu yang dipakai oleh Masyarakat tutur antara Desa Betung dengan Desa Kesuma. Penulis menemukan 71 perbedaan kosakata yang akan dianalisis berdasarkan perbedaan semantis yakni sinonim. Penulis juga menemukan 6 perbedaan kosakata yang akan dianalisis berdasarkan perbedaan semantis yakni homonim. Penulis juga mendapatkan hasil penelitian yakni faktor yang mepengaruhi perbedaan kosakata yang dipakai oleh masyarakat tutur di Desa Betung dengan Desa Kesuma.

Kata Kunci: Perbedaan, Kosakata, dialek, variasi bahasa

Perbedaan Kosakata Dialek Melayu di Desa Betung dengan Desa Kesuma Kecamatan 


\section{PENDAHULUAN}

Menjadi negara yang diakui kekayaannya, Republik Indonesia tentu saja tidak dapat dipandang sebelah mata oleh dunia. Tidak hanya dari sektor kekayaan alam, tetapi dari segala segi negara ini dapat dikatakan kaya. Termasuk juga kedalamnya kaya akan keragaman. Indonesia adalah negara dengan berbagai macam ras, suku, budaya, adat, tradisi, maupun bahasa.

Berbicara tentang bahasa, bahasa merupakan alat komunikasi yang digunakan untuk menyampaikan informasi antar anggota masyarakat. Bahasa dalam perannya sebagai alat komunikasi dapat diartikan yakni seorang penutur menyampaikan tuturannya kepada mitra tutur guna menyampaikan informasi dengan tujuan mendapatkan respon atau menimbulkan reaksi kepada mitra tutur. Alek (2018:7) menjelaskan bahwa bahasa itu adalah lambang yang berwujud bunyi. Lambang yang bermakna sesuatu, melambangkan sesuatu yaitu pengertian, suatu konsep, ide, atau pikiran. Bahasa itu memiliki makna, karena itulah bahasa dapat digunakan sebagai alat komunikasi.

Bahasa tidak dapat dipisahkan dari budaya penuturnya. Pada suatu kelompok masyarakat, penutur akan menggunakan bahasa yang dimengerti oleh anggota kelompok masyarakatnya. Hal ini terlepas dari adanya bahasa persatuan bahasa Indonesia, bahasa daerah masih tetap digunakan hingga saat ini. Meski masyarakat menggunakan bahasa persatuan yakni bahasa Indonesia dalam berkomunikasi, tetapi bahasa daerah yang hingga saat ini masih terjaga kelestariannya tetap menjadi suatu ciri khas dari bangsa ini. Adanya perbedaan bahasa daerah di setiap wilayah Indonesia mampu memperlihatkan satu sifat bahasa yakni bahasa itu unik. Oleh karenanya, Kailani Hasan (2001:13) mengatakan bahwa bahasa itu merupakan suatu sistem, dari simbolsimbol vokal yang sifatnya arbitrer dan dipakai oleh anggota masyarakat untuk berkomunikasi, dan bahasa selaras dengan budaya lokal masyarakat tersebut.

Salah satu bahasa daerah yang memiliki rumpun besar di Indonesia yakni bahasa Melayu. Provinsi Riau merupakan salah satu provinsi dengan mayoritas masyarakat yang memakai bahasa Melayu dalam berkomunikasi. Sejak zaman kerajaan Sriwijaya, bahasa Melayu sudah menjadi bahasa internasional atau lingua franca di kepulauan Nusantara. Bahasa Melayu di Riau dikenal dengan bahasa Melayu Riau. Bahasa Melayu Riau sendiri memiliki beraneka ragam dialek, tergantung pada daerah pemakainya.

Bahasa dan lingkungan sosial memang tidak dapat dipisahkan. Dalam sosiolinguistik terdapat istilah dialek atau bahasa yang digunakan oleh golongan orang-orang tertentu. Misalnya, bahasa kantor, bahasa pegawai, bahasa guru dan sebagainya. Begitupun bahasa Melayu yang ada di Riau. Bahasa Melayu di Riau juga tidak terlepas dari adanya perbedaan-perbedaan antar daerahnya. Perbedaan-perbedaan ini baik dari segi pelafalan, bunyi, kosakata, makna, serta arti. Salah satu contohnya yaitu perbedaan dialek yang ada pada bahasa Melayu Riau di Kabupaten Pelalawan. Perbedaan ini membuktikan bahwa adanya keragaman dalam bahasa.

Pangkalan Kuras merupakan salah satu kecamatan yang berada di Kabupaten Pelalawan. Pelalawan sendiri adalah kabupaten hasil perpecahan dari Kabupaten Kampar. Bahasa Melayu yang dipakai di Pelalawan mirip dengan bahasa Melayu yang dipakai di Kabupaten Kampar. Namun ternyata di beberapa desa dalam satu lingkup wilayah kecamatan yang ada di Pelalawan terdapat perbedaan-perbedaan kosakata yang dipakai oleh masyarakatnya antara desa yang satu dengan desa yang lain. Tulisan ini akan fokus pada bahasa Melayu dialek Pangkalan Kuras. Umumnya pada 17 desa atau kelurahan di Kecamatan Pangkalan Kuras ini masyarakat memakai bahasa Melayu dengan dialek yang sama.

Bahasa Melayu yang dipakai oleh masyarakat Pangkalan Kuras dalam komunikasinya seharihari merupakan bahasa Melayu yang biasa dikenal dengan bahasa Melayu darat. Bahasa Melayu yang dipakai merupakan bahasa Melayu yang dominan menggunakan akhiran /o/. Misalnya untuk kata dimana, maka di Pangkalan Kuras akan menjadi dimano. Fenomena keragaman yang akan menjadi fokus penulis dalam penelitian ini adalah adanya perbedaan kosakata yang digunakan oleh masyarakat di Desa Betung dengan masyarakat di Desa Kesuma di Kecamatan Pangkalan Kuras. Padahal, jika ditinjau secara geografis, jarak kedua desa ini tidak jauh. Jarak dari Desa Betung menuju 
Desa Kesuma hanya sekitar 3 menit perjalanan.

Terdapat beberapa kejadian yang melatarbelakangi penulis dalam penelitian ini. Kejadian pertama, saat penulis berada di Pasar Tradisional di Kecamatan Pangkalan Kuras tepatnya di Pasar Baru Sorek Satu, penulis mendengar perbedaan penggunaan kata ganti orang yang dipakai oleh masyarakat dari Desa Betung dan Desa Kesuma. Oleh masyarakat Desa Betung kata ganti orang pertama menggunakan kata (aku), sedangkan oleh masyarakat Desa Kesuma menggunakan kata (ambo). Penulis juga mendengar percakapan antara masyarakat Desa Betung dengan masyarakat Desa Kesuma yang mengandung perbedaan kosakata. Seperti kata [tiak] oleh masyarakat Desa Kesuma memiliki arti (panggil). Sedangkan, masyarakat Desa Betung akan menjawab dengan kata [imbau].

Kejadian kedua, saat penulis berkunjung ke rumah salah satu saudara yang berada di Desa Betung, penulis mengamati penggunaan bahasa Melayu yang digunakan oleh masyarakat Desa Betung. Penulis mengamati penggunaan salah satu kosakata yang digunakan masyarakat Desa Betung, yakni pada kata [uang] di Desa Betung disepakati memiliki arti (orang).

Kejadian ketiga, pada saat penulis berkunjung ke Desa Kesuma yang hanya berjarak sekitar 3 menit dari Desa Betung, penulis mengamati bahasa Melayu yang digunakan oleh masyarakat Desa Kesuma yang terdengar berbeda dari masyarakat Desa Betung. Padahal jarak kedua Desa ini tidak jauh. Penulis mengamati penggunaan kosakata oleh masyarakat di Desa Kesuma. Masyarakat Desa Kesuma menyepakati untuk kata (orang) memiliki arti [oong]. Dari ketiga kejadian ini, penulis melihat ada perbedaan penggunaan kosakata pada bahasa Melayu di kedua desa ini. Penulis juga meyakini masih banyak terdapat perbedaan kosakata yang digunakan dalam bahasa Melayu yang digunakan di kedua desa ini.

\section{METODOLOGI PENELITIAN}

Jenis penelitian ini adalah penelitian kualitatif yang menggunakan metode analisis deskriptif. Penelitian ini dilakukan di daerah kecamatan Pangkalan Kuras, khususnya di dua tempat yakni di Desa Betung dan Desa Kesuma, Kabupaten Pelalawan, Provinsi Riau. Data dalam penelitian ini berupa kosakata dari bahasa Melayu dialek Pangkalan Kuras, Kabupaten Pelalawan. Data bersumber dari kalimat-kalimat atau tuturan yang dituturkan oleh masyarakat di Desa Betung dan Desa Kesuma dalam kehidupan sehari-hari.

Data dikumpulkan melalui metode observasi, wawancara, teknik simak libat cakap, dan juga teknik catat. Penulis bertindak sebagai instrumen penelitian sekaligus pengumpul data. Selain itu, instrumen penelitian juga berupa draf pertanyaan, pedoman wawancara, dan pedoman observasi. Data dianailisis dengan langkah kerja, yakni pertama tahap mereduksi data, selanjutnya penyajian data, terakhir menyimpulkan. Keabasahan data diperiksa dengan beberapa cara, yaitu periksa silang antar informan, kecukupan referensi, serta diskusi.

\section{HASIL DAN PEMBAHASAN}

Berdasarkan proses penelitian yang telah dilakukan oleh penulis, ditemukan hasil penelitian yakni perbedaan kosakata dialek Melayu yang dipakai oleh Masyarakat tutur antara Desa Betung dengan Desa Kesuma. Penulis menemukan 71 perbedaan kosakata yang akan dianalisis berdasarkan perbedaan semantis yakni sinonim. Penulis juga menemukan 6 perbedaan kosakata yang akan dianalisis berdasarkan perbedaan semantis yakni homonim. Penulis juga mendapatkan hasil penelitian yakni faktor yang mepengaruhi perbedaan kosakata yang dipakai oleh masyarakat tutur di Desa Betung dengan Desa Kesuma.

\section{Perbedaan Kosakata Sinonim (Pemberian nama yang berbeda untuk hal yang sama)}

Sinonim merupakan kata yang memiliki bentuk yang berbeda namun memiliki arti yang sama atau mirip. Sinonim dapat diartikan juga sebagai hubungan semantik yang menyatakan adanya kesamaan makna antara satu kata dengan kata lainnya. Sinonim sering disebut sebagai padanan kata atau persamaan kata. Data sinonim dalam penelitian ini bersumber dari tuturan masyarakat dari Desa Betung dan Desa Kesuma sebagai tempat penelitian. Untuk lebih jelasnya dapat diliihat pada tabel berikut beserta analisisnya : 
GERAM (GERAKAN AKTIF MENULIS)

P-ISSN 2338-0446

Volume 9, Nomor 1, Juni 2021

E-ISSN 2580-376X

Tabel 1. Perbedaan Kosakata Sinonim

\begin{tabular}{|c|c|c|c|}
\hline No & $\begin{array}{l}\text { Bahasa } \\
\text { Indonesia }\end{array}$ & $\begin{array}{l}\text { Dialek } \\
\text { Betung }\end{array}$ & $\begin{array}{c}\text { Dialek } \\
\text { Desa } \\
\text { Kesuma }\end{array}$ \\
\hline 1. & saya & aku & ambo \\
\hline 2. & kamu & dikau & ngkau \\
\hline 3. & dia & inyo & dio \\
\hline 4. & kalian & ingkak & mingkak \\
\hline 5. & Mereka & Uang du & Oong du \\
\hline 6. & amanat & deso & posan \\
\hline 7. & angkat & bangkit & angkit \\
\hline 8. & atas & ate & atas \\
\hline 9. & bandel & bingal & okak \\
\hline 10. & barang & pekake & pekakas \\
\hline 11. & bayar & baye & bayo \\
\hline 12. & belajar & belaje & belajo \\
\hline 13. & beras & boe & boas \\
\hline 14. & bercanda & beguau & seloo \\
\hline 15. & beri & boi & bagi \\
\hline 16. & $\begin{array}{l}\text { berkeringat } \\
\text { karena } \\
\text { cuaca }\end{array}$ & polak & hadang \\
\hline 17. & berlari & kengkojean & kekojoan \\
\hline 18. & bertemu & besuo & betomu \\
\hline 19. & besar & bose & boso \\
\hline 20. & biar & bie & bio \\
\hline 21. & belum & olum & bolum \\
\hline 22. & celana & selue & celana \\
\hline 23. & cemas & come & comas \\
\hline 24. & dengar & donge & dongo \\
\hline 25. & $\begin{array}{l}\text { hangus } \\
\text { tetapi masih } \\
\text { bisa } \\
\text { dimakan }\end{array}$ & angui & angus \\
\hline 26. & $\begin{array}{l}\text { hangus/goso } \\
\text { ng }\end{array}$ & kuyang & kuntang \\
\hline 27. & jahe & lio & jahe \\
\hline 28. & kecil & kocit & kocik \\
\hline 29. & kelapa & nio & niau \\
\hline 30. & keluar & kelue & keluo \\
\hline 31. & kencur & coku & kencur \\
\hline 32. & keras & koe & koas \\
\hline 33. & $\begin{array}{l}\text { kerongkong } \\
\text { an }\end{array}$ & kongkung & tokak \\
\hline 34. & kertas & kote & kotas \\
\hline 35. & lapar & lape & lapo \\
\hline 36. & lelet & lembin & compam \\
\hline 37. & lempar & umban & lempo \\
\hline 38. & lengkuas & lengkueh & lengkuas \\
\hline 39. & longgar & lungge & longgo \\
\hline 40. & luas & lueh & luas \\
\hline 41. & melamun & temonung & tenonung \\
\hline 42. & membersihk & menobe & men \\
\hline
\end{tabular}

\begin{tabular}{|c|c|c|c|}
\hline & an ladang & & \\
\hline 43. & menangis & menangi & menanges \\
\hline 44. & $\begin{array}{l}\text { menyadap } \\
\text { getah karet }\end{array}$ & motung & nakik \\
\hline 45. & nanti & kian & kaang \\
\hline 46. & orang & uang & oong \\
\hline 47. & $\begin{array}{l}\text { orang yang } \\
\text { kebingunga } \\
\mathrm{n}\end{array}$ & teingo-ingo & teilu-ilu \\
\hline 48. & panas & angat & panas \\
\hline 49. & panggil & imbau & tiak \\
\hline 50. & pasar & pase & paso \\
\hline 51. & pedas & pode & podas \\
\hline 52. & peras & poe & poas \\
\hline 53. & pergi & poi & pogi \\
\hline 54. & $\begin{array}{l}\text { pergi } \\
\text { dengan cara } \\
\text { diusir }\end{array}$ & beambui & beambus \\
\hline 55. & potong & koat & potung \\
\hline 56. & rebus & obui & obus \\
\hline 57. & robek & kuyak & koyak \\
\hline 58. & sadar & sode & sado \\
\hline 59. & sebuah & sebua & sebuti \\
\hline 60. & seperti & supo & macam \\
\hline 61. & sering & kodap & koap \\
\hline 62. & tahu & obe & tontu \\
\hline 63. & terbakar & tebake & tebako \\
\hline 64. & $\begin{array}{l}\text { teringin } \\
\text { sesuatu }\end{array}$ & tekoce & tiagak \\
\hline 65. & tertabrak & tetobung & telanggo \\
\hline 66. & tertawa & golak & tetao \\
\hline 67. & terasa & taso & tiaso \\
\hline 68. & tidak & indak & tidak \\
\hline 69. & tidur & memuto & miabun \\
\hline 70. & tikar & tike & tiko \\
\hline 71. & ular & ule & ulo \\
\hline
\end{tabular}

Berikut merupakan analisis dari beberapa perbedaan kosakata yang ada pada tabel di atas. Analisis perbedaan kosakata yang akan dilihat dari perbedaan secara sinonimnya.

(1) kata [saya] dalam dialek Melayu di Desa Betung disebut [aku], sedangkan dalam dialek Melayu di Desa Kesuma disebut [ambo]. Dari datum ini dapat kita lihat adanya perbedaan penggunaan kosakata untuk kata ganti orang pertama yang dipakai oleh masyarakat tutur di Desa Betung dengan Desa Kesuma. Namun, masyarakat tutur menyepakati perbedaan kata ganti ini, kata [aku] dengan [ambo] tetap memiliki arti yang sama. Contoh kalimat :

Dialek Melayu di Desa Betung : 
"Aku poi ke pase"

Dialek Melayu di Desa Kesuma :

"Ambo pogi ke paso"

Terjemahan : "Saya pergi ke pasar".

(2) kata [kamu] dalam dialek Melayu di

Desa Betung disebut dengan [dikau], sedangkan dalam dialek Melayu di Desa Kesuma disebut [engkau]. Dari datum ini dapat kita lihat adanya perbedaan penggunaan kosakata untuk kata ganti orang kedua yang dipakai oleh masyarakat tutur di Desa Betung dengan Desa Kesuma. Namun, masyarakat tutur menyepakati perbedaan kata ganti ini, kata [dikau] dengan [engkau] tetap memiliki arti yang sama. Contoh kalimat :

Dialek Melayu di Desa Betung :

"Dikau ola makan?"

Dialek Melayu di Desa Kesuma :

"Engkau ola makan?"

Terjemahan : "Kamu sudah makan?".

(3) kata [kalian] dalam dialek Melayu di Desa Betung disebut [ingkak], sedangkan dalam dialek Melayu di Desa Kesuma disebut dengan [mingkak]. Dari datum ini dapat kita lihat adanya penambahan konsonan $/ \mathrm{m} /$ pada kata [mingkak] yang dituturkan oleh masyarakat tutur Desa Kesuma, sehingga terdapat perbedaan kosakata untuk kata ganti orang kedua jamak yang dipakai oleh masyarakat tutur di Desa Betung dengan Desa Kesuma. Namun, masyarakat tutur menyepakati bahwa kata [ingkak] dan kata [mingkak] memiliki arti yang sama. Contoh kalimat :

Dialek Melayu di Desa Betung

"Ingkak nak poi kemano du?"

Dialek Melayu di Desa Kesuma :

"Mingkak nak pogi kemano du?"

Terjemahan: "Kalian mau pergi kemana itu?".

(4) kata [amanat yang harus disampaikan kepada orang lain] dalam dialek Melayu di Desa Betung dituturkan dengan [deso], sedangkan dalam dialek Melayu di Desa Kesuma disebut dengan [posan]. Dari datum ini dapat ini dapat kita lihat tidak terjadi perubahan arti pada kata [deso] dan kata [posan], tetapi yang terdapat ialah perbedaan kosakata. Contoh kalimat :

Dialek Melayu di Desa Betung :

"Tadi ola aku desoan pado Adi la suu Uba nyo datang kumah awak"

Dialek Melayu di Desa Kesuma :
"Tadi la ambo posan padi Adi nyo suu Uba dio datang kumah awak"

Terjemahan : "Tadi sudah saya amanatkan kepada Adi, bahwa kita mengundang Ayahnya ke rumah kita".

(5) kata [bandel] dalam dialek Melayu di Desa Kesuma dituturkan dengan [bingal], sedangkan dalam dialek Melayu di Desa Kesuma disebut dengan [okak]. Dari datum ini dapat kita lihat perbedaan kosakata pada kata [bandel] diantara kedua desa ini. Tetapi, masyarakat menyepakati bahwa kata [bingal] dan [okak] memiliki arti yang sama. Contoh kalimat :

Dialek Melayu di Desa Betung :

"Nyo dikau bingal,indak manonge cakap uang",

Dialek Melayu di Desa Kesuma :

"Nyo engkau okak, tak nongo cakap oong "

Terjemahan : "Kamu ini bandel, tidak mau mendengarkan nasihat orang lain".

(6) kata [barang] dalam dialek Melayu di Desa Betung disebut [pekake], sedangkan dalam dialek Melayu di Desa Kesuma disebut [pekakas]. Dari datum ini dapat kita lihat terdapat perbedaan penggunaan kosakata pada kata [barang]. Namun, masyarakat menyepakati bahwa kata [pekake] dan kata [pekakas] memiliki arti yang sama. Contoh kalimat :

Dialek Melayu di Desa Betung:

"Pekake siapo yang beseak-seak ko?"

Dialek Melayu di Desa Kesuma :

"Pekakas siapo yang beseak-seak ni?"

Terjemahan: "Barang siapa ini yang berantakan sekali?".

(7) kata [bayar] dalam dialek Melayu di Desa Betung dituturkan [baye], sedangkan dalam dialek Melayu di Desa Kesuma disebut [bayo]. Dari datum ini dapat kita lihat terdapat perbedaan fonem, yakni di Desa Betung menggunakan fonem /e/, sedangkan di Desa Kesuma menggunakan fonem $/ \mathrm{o} /$, sehingga terjadi perbedaan kosakata yang digunakan antara kedua desa. Namun, masyarakat menyepakati bahwa kata [baye] dan kata [bayo] memiliki arti yang sama. Contoh kalimat :

Dialek Melayu di Desa Betung :

"Didi, utang dikau dibaye"

Dialek Melayu di Desa Kesuma :

"Didi, utang engkau dibayo"

Terjemahan : "Didi, bayarlah Utangmu". 
(8) kata [bercanda] dalam dialek Melayu di Desa Betung disebut [beguau], sedangkan dalam dialek Melayu di Desa Kesuma disebut [seloo]. Dari datum ini dapat kita lihat adanya perbedaan penggunaan kosakata yang digunakan oleh masyarakat tutur di Desa Betung dengan masyarakat tutur di Desa Kesuma. Namun, masyarakat menyepakati bahwa kata [beguau] dengan kata [seloo] memiliki makna yang sama. Contoh kalimat :

Dialek Melayu di Desa Betung :

"Jangan tesinggung dikau le,beguau aku nyo"

Dialek Melayu di Desa Kesuma :

"Engkau jangan tesinggung, ambo seloo nyo"

Terjemahan : "Kamu jangan tersinggung ya, saya hanya bercanda".

(9) kata [celana] dalam dialek Melayu di Desa Betung disebut [selue], sedangkan dalam dialek Melayu di Desa Kesuma disebut [celana]. Dari datum ini dapat dilihat terdapat perbedaan penggunaan kosakata pada kata [celana] oleh masyarakat tutur di Desa Betung dan Desa Kesuma. Namun, masyarakat tutur menyepakati bahwa kata [selue] dan kata [celana] memiliki arti yang sama. Contoh kalimat :

Dialek Melayu di Desa Betung :

"Bose selue dikau ko Adik"

Dialek Melayu di Desa Kesuma :

"Boso celana engkau ni Adik"

Terjemahan: "Besar sekali celana kamu ini Adik".

(10) kata [hangus;gosong] kata hangus pada datum ini merujuk kepada masakan yang gosong karena ditinggal terlalu lama bahkan sampai kehitam-hitaman dan tidak bisa dimakan lagi. Dalam dialek Melayu di Desa Betung, [hangus;gosong] ini disebut dengan [kuyang], sedangkan dalam dialek Melayu di Desa Kesuma disebut [kuntang]. Dari datum ini dapat kita lihat perbedaan penggunaan kosakata yang digunakan masyarakat tutur Desa Betung dengan Desa Kesuma. Namun, masyarakat tutur menyepakati bahwa kata [kuyang] dan kata [kuntang] memiliki arti yang sama. Contoh kalimat :

Dialek Melayu di Desa Betung

"Abi la kuyang gulai ko"

Dialek Melayu di Desa Kesuma :

"Abis la kuntang gulai ni a"
Terjemahan: "Gulai ini sudah gosong sekali".

2. Perbedaan kosakata homonim (pemberian nama yang sama untuk hal yang berbeda)

Homonim dalam penelitian dialek Melayu di Desa Betung dengan Desa Kesuma, Kecamatan Pangkalan Kuras, Kabupaten Pelalawan ini terdapat pada kata [tetao, kocik, memotung, paso, ajo, kuntang]. Untuk lebih jelasnya dapat dilihat pada tabel berikut beserta pembahasannya :

\section{Tabel 2. Perbedaan Kosakata Homonim}

\begin{tabular}{|c|c|c|c|}
\hline No. & Kosakata & $\begin{array}{c}\text { Arti dalam } \\
\text { Dialek } \\
\text { Betung }\end{array}$ & $\begin{array}{c}\text { Arti dalam } \\
\text { Dialek Desa } \\
\text { Kesuma }\end{array}$ \\
\hline 1. & tetao & $\begin{array}{l}\text { Menabrak } \\
\text { sesuatu tanpa } \\
\text { disengaja }\end{array}$ & tertawa \\
\hline 2. & kocik & $\begin{array}{l}\text { Kantong pada } \\
\text { baju atau } \\
\text { celana }\end{array}$ & kecil \\
\hline 3. & memotung & $\begin{array}{l}\text { Aktivitas } \\
\text { menyadap } \\
\text { getah karet }\end{array}$ & memotong \\
\hline 4. & paso & paksa & pasar \\
\hline 5. & ajo & raja & ajar \\
\hline 6. & kuntang & $\begin{array}{l}\text { Habis tanpa } \\
\text { sisa }\end{array}$ & hangus \\
\hline
\end{tabular}

Berikut merupakan hasil analisis dari perbedaan kosakata dialek Melayu di Desa Betung dengan dialek Melayu di Desa Kesuma yang dilihat secara homonim seperti pada tabel di atas:

a. kata [tetao] dalam dialek Melayu di Desa Betung memiliki arti (menabrak sesuatu tanpa disengaja), sedangkan dalam dialek Melayu di Desa Kesuma kata [tetao] memiliki arti (tertawa). Dari data ini dapat kita lihat pada kata [tetao] dalam dialek Melayu di Desa Betung memiliki perbedaan arti dengan dialek Melayu di Desa Kesuma.

b. kata [kocik] dalam dialek Melayu di Desa Betung memiliki arti (kantong pada baju atau celana), sedangkan dalam dialek Melayu di Desa Kesuma kata [kocik] memiliki arti (kecil). Dari data ini dapat kita lihat perbedaan arti pada kata [kocik] dalam dialek Melayu antara Desa Betung dengan Desa Kesuma.

c. kata [memotung] dalam dialek Melayu di Desa Betung memiliki arti (aktivitas menyadap getah

Perbedaan Kosakata Dialek Melayu di Desa Betung dengan Desa Kesuma Kecamatan 70

Pangkalan Kuras Kabupaten Pelalawan 
karet), sedangkan dalam dialek Melayu di Desa Kesuma kata [memotung] memiliki arti (memotong). Dari data ini dapat kita lihat pada kata [memotung] dalam dialek Melayu di Desa Betung memiliki perbedaan arti dengan dialek Melayu di Desa Kesuma.

d. Kata [paso] dalam dialek Melayu di Desa Betung memiliki arti (paksa), sedangkan dalam dialek Melayu di Desa Kesuma kata [paso] memiliki arti (pasar). Dari data ini dapat kita lihat pada kata [paso] dalam dialek Melayu di Desa Betung memiliki perbedaan arti dengan dialek Melayu di Desa Kesuma.

e. Kata [ajo] dalam dialek Melayu di Desa Betung memiliki arti (raja), sedangkan dalam dialek Melayu di Desa Kesuma kata [ajo] memiliki arti (ajar). Dari data ini dapat kita lihat pada kata [ajo] dalam dialek Melayu di Desa Betung memiliki perbedaan arti dengan dialek Melayu di Desa Kesuma.

f. kata [kuntang] dalam dialek Melayu di Desa Betung memiliki arti (habis tanpa sisa), sedangkan dalam dialek Melayu di Desa Kesuma kata [kuntang] memiliki arti (hangus). Dari data ini dapat kita lihat pada kata [kuntang] dalam dialek Melayu di Desa Betung memiliki perbedaan arti dengan dialek Melayu di Desa Kesuma.

\section{PEMBAHASAN}

Kridalaksana (dalam Tarigan, 1994: 446) menjelaskan bahwa kosakata adalah komponen bahasa yang memuat secara infromasi tentang makna dan pemakaian kata dalam bahasa. Menurutnya, kosakata juga berarti kekayaan kata yang dimiliki oleh seseorang. Secara gramatikal, kosakata merupakan daftar kata yang disusun seperti kamus, tetapi dengan penjelasan yang singkat dan praktis.

Soedjito (dalam Tarigan, 1994: 447) mengatakan bahwa kosakata adalah semua kata yang terdapat dalam suatu bahasa. Dalam Kamus Besar Bahasa Indonesia, kosakata didefinisikan sebagai pembendaharaan kata. Sedangkan bahasa adalah suatu sistem yang sifatnya arbitrer dapat berupa simbol bunyi yang selaras dengan budaya penuturnya dan digunakan sebagai alat komunikasi. Kosakata merupakan bagian dari bahasa yan tidak dapat dipisahkan. Sebuah bahasa pasti kaya akan kosakata. Kosakata ini merupakan bantuan yang besar bagi bahasa untuk dapat menjalankan fungsi bahasa itu sendiri.

Dalam ilmu bahasa, ada lagi sebuah istilah yang dikenal dengan dialek. Dialek juga merupakan bagian dari bahasa yang tidak dapat dipisahkan. dialek merupakan variasi bahasa yang terdapat dalam satu kelompok penutur, yang dipadankan dengan logat dan disebabkan oleh beberapa faktor seperti perbatasan wilayah. Dalam dialek terdapat perbedaan satu dengan lain tetapi masih banyak menunjukkan kemiripan sehingga belum dapat dikatakan bahwa perbedaan itu merupakan perbedaan bahasa.

Meillet (dalam Ayatrohaedi, 1983:2) mengatakan bahwa ciri utama dalam dialek itu adalah perbedaan dalam kesatuan dan kesatuan dalam perbedaan. Meillet (dalam Ayatrohaedi, 1983:2) menjelaskan bahwa adapun ciri lain dari dialek yakni (1) dialek merupakan seperangkat bentuk ujaran setempat yang berbeda-beda, yang memiliki ciri umum dan masing-masing lebih mirip sesamanya dibandingkan dengan bentuk ujaran lain dari bahasa yang sama. (2) Dialek tidak harus mengambil semua bentuk ujaran dari sebuah bahasa. Dalam perkembangnnya dialek merujuk kepada suatu bahasa daerah yang layak dipergunakan di dalam karya Sastra.

Ayatrohaedi (1983:3) secara garis besar, terdapat lima macam yang menjadi pembeda dialek. Yaitu :

\section{a. Perbedaan Fonetik}

Perbedaan ini berada di bidang fonologi. Biasanya si penutur yang bersangkutan tidak menyadari adanya perbedaan.

\section{b. Perbedaan Semantik}

Perbedaan ini menciptakan kata-kata baru, berdasarkan perubahan fonologi dan geseran bentuk. Dalam peristiwa tersebut biasanya juga terjadi pergeseran makna. Geseran makna ini merujuk kepada dua corak. Pertama, pemberian nama yang berbeda untuk objek yang sama di beberapa tempat yang berbeda. Geseran corak ini disebut dengan sinonim atau padan kata. Kedua, pemberian nama yang sama untuk hal yang berbeda di beberapa tempat yang berbeda atau dikenal dengan homonim.

\section{c. Perbedaan Onomasiologis}

Perbedaan onomasiologis merupakan menunjukkan nama yang berbeda berdasarkan suatu konsep yang diberikan di beberapa tempat 
yang berbeda.

d. Perbedaan Semasiologis

Perbedaan ini merupakan kebalikan dari perbedaan onomasiologis. Yaitu pemberian nama yang sama untuk beberapa konsep yang berbeda.

e. Perbedaan Morfologis

Yakni perbedaan yang dibatasi karena adanya sistem tata bahasa yang bersangkutan, oleh frekuensi morfem yang berbeda, oleh kegunaannya yang berkerabat oleh wujud fonetisnya, daya rasanya, serta sejumlah faktor lainnya.

Dialek merupakan bagian dari variasi bahasa. Variasi bahasa berkembang sedemikian rupa dan menjadikan variasi ini sebagai ciri budaya suatu kelompok tertentu. Suatu bahasa yang berkembang dan masyarakat terdiri atas golongan kelompok maka variasi bahasanya akan terbentuk sesuai dengan kebutuhan, fungsi, dan keperluan kelompok. Variasi bahasa didasari oleh beberapa faktor, misalnya perbedaan tempat atau wilayah, waktu, pemakaian bahasa, situasi dan status bahasa (Hasnah Faizah, 2008:127).

oleh karena itu, dalam penelitian ini terjadi sebuah fenomena dimana ada dua buah desa dengan jarak yang sangat dekat dengan bahasa yang sama, dialek yang sama, namun ternyata pada tuturan masyarakatnya dalam kehidupan sehari-hari terdapat perbedaan penggunaan kosakata. Meski sama-sama berbahasa Melayu dialek Pangkalan Kuras, Kabupaten Pelalawan, ternyata kedua desa ini banyak menggunakan kosakata yang berbeda dalam tuturannya.

Perbedaan kosakata dalam suatu dialek yang sama ternyata merupakan suatu hal yang lumrah terjadi. Inilah yang dimaksud dengan bahasa itu bervariasi. Bahasa itu bermacammacam. Meskipun awalnya menimbulkan pertanyaan bahwa mengapa dua desa dengan jarak yang sangat dekat, bahkan jika dilihat sekali jalan dua desa ini seperti hanya satu desa, dengan bahasa melayu dan dialek yang sama namun ternyata memakai banyak kosakata yang berbeda dalam tuturan masyarakatnya.

Setelah dilakukannya penelitian ini, penulis juga menemuka faktor yang memengaruhi terjadinya perbedaan kosakata yang dipakai oleh masyarakat di Desa Betung dengan masyarakat Desa Kesuma. Faktor pertama yaitu, adanya perpindahan penduduk dari penduduk perairan menjadi penduduk darat. Penduduk Desa Kesuma yang awalnya bermukim di perairan naik ke darat dan bermukim di darat. sehingga kosakata yang mereka pakai masih kosakata Melayu perairan. Sedangkan masyarakat Desa Betung merupakan penduduk asli daratan.

Faktor kedua yang memengaruhi terjadinya perbedaan penggunaan kosakata di Desa Betung dengan Desa Kesuma adalah adanya perbedaan suku. Berdasarkan tuturan narasumber, masyarakat yang berada di Desa Kesuma disebut dengan saio baini, sedangkan masyarakat yang berada di Desa Betung disebut dengan uang kampung. Masyarakat Desa Betung merupakan penduduk asli suku Petalangan, sehingga bahasa yang dipakai masyarakatnya yaitu bahasa darat. Sedangkan masyarakat Desa Kesuma merupakan masyarakat suku perairan yang pindah ke darat, sehingga bahasa yang dipakai masyarakatnya yaitu bahasa laut. Jadi, adanya perbedaa suku ini juga menjadi faktor lain yang memengaruhi adanya perbedaan penggunaan kosakata dalam dialek Melayu di Desa Betung dengan Desa Kesuma.

\section{SIMPULAN}

Adapun kesimpulan yang dapat diambil dalam penelitian ini adalah sebagai berikut:

1. Adanya Perbedaan Kosakata dalam dialek Melayu di Desa Betung dengan Desa Kesuma

Pada penelitian ini, terdapat perbedaan penggunaan kosakata oleh Masyarakat tutur yang ada di Desa Betung dan Desa Kesuma. Meskipun jarak antara kedua desa ini sangatlah dekat. Dari hasil penelitian beserta analisisnya, ditemukan (71) perbedaan Kosakata yang dipakai oleh masyarakat tutur antara Desa Betung dengan Desa Kesuma. (71) kosakata ini dianalisis secara semantis yakni berupa sinonim. Maksudnya ialah, terdapat (71) kosakata yang berbeda yang dipakai di Desa Betung dengan Desa Kesuma namun disepakati memiliki arti yang sama.

Pada penelitian ini juga ditemukan perbedaan penggunaan kosakata berjumlah (6) kosakata yang dianalisis secara semantis yaitu berupa homonim. Kosakata tersebut yakni [tetao, kocik, memotung, paso, ajo, kuntang]. Homonim adalah pemberian nama yang sama untuk hal yang berbeda. Jadi, ke enam kata ini sama-sama dipakai di Desa Betung

Perbedaan Kosakata Dialek Melayu di Desa Betung dengan Desa Kesuma Kecamatan 72

Pangkalan Kuras Kabupaten Pelalawan 
dan Desa Kesuma, namun disepakati memiliki arti yang berbeda.

2. Adanya faktor yang memengaruhi adanya perbedaan kosakata di Desa Betung dengan Desa Kesuma.

Dari hasil penelitian, dapat disimpulkan bahwa terdapat 2 faktor yang memengaruhi adanya perbedaan kosakata yang dipakai oleh masyarakat tutur di Desa Betung dengan Desa Kesuma. Pertama, adanya perpindahan penduduk yang terjadi pada zaman dahulu. Yaitu, penduduk Desa Kesuma saat ini merupakan penduduk perairan yang dulunya bermukim di Sungai Napuh lalu naik dan bermukim di darat. Sehingga masyarakatnya masih menggunakan bahasa perairan meskipun sudah bermukim di darat. Sedangkan masyarakat Desa Betung merupakan penduduk asli di wilayah tersebut dan mempertahankan bahasa Melayu darat. Karenanya, terdapat perbedaan kosakata di Desa Betung dengan Desa Kesuma. Kedua, adanya perbedaan suku dari kedua masyarakat. Masyarakat di Desa Betung sebagian besar merupakan masyarakat bersuku Melayu petalangan atau disebut dengan "uang kampung" sehingga bahasa yang dipakai bahasa darat. Sedangkan masyarakat di Desa Kesuma kebanyakan merupakan masyarakat bersuku laut atau disebut dengan "saio baini" sehingga bahasa yang dipakai ialah bahasa laut.

Itulah kedua faktor yang memengaruhi adanya perbedaan kosakata dalam dialek Melayu di Desa Betung dengan Desa Kesuma, Kecamatan Pangkalan Kuras, Kabupaten Pelalawan.

\section{DAFTAR PUSTAKA}

Alek. 2008. Linguistik. Jakarta: Erlangga.

Ayatrohaedi. 1983. Dialektologi sebuah

Pengantar. Jakarta. Pusat Pembinaan dan Pengembangan Bahasa Departemen Pendidikan dan Kebudayaan.

Faizah, H. 2008. Lingusitik Umum. Pekanbaru: Cendikia Insani.

Hasan, K. 2001. Linguistik Umum dan Sosiolinguistik. Pekanbaru: Unri Press.

Tarigan, H. G. 1994. Pengajaran Kosakata. Bandung : Angkasa Raya 